January 2020, VOLUME 8, ISSUE 1, 18-38

E-ISSN NO: $2289-4489$

\title{
DESIGNING INQUIRY-BASED EXPERTISE SHARING MODEL TO ENHANCE GRADUATE EMPLOYABILITY IN HIGHER EDUCATION INSTITUTIONS
}

Feri Noperman, Safnil Arsyad, Endang Widi Winarni Dalifa \& Endina Putri Purwandari

University of Bengkulu, INDONESIA

Corresponding Author:

E-mail: ferinoperman@unib.ac.id

\section{ABSTRACT}

This study aims to design Inquiry-Based Expertise Sharing (IBES) as a comprehensive active learning model in higher education, and then to examine its strength and challenges in enhancing graduate employability. This research was conducted by combination of qualitative and quantitative methods. There were two phases namely developing a pilot project and conducting experimental testing. In first phase, an initial comprehensive learning framework was developed by combining and integrating Jigsaw, Inquiry-Based Learning, and Knowledge Sharing as a framework named Inquiry-Based Expertise Sharing (IBES). In the second phase, the revised IBES was experimentally tested in the same course but different students using quasi-experiment method and the matching only pre-test post-test control group design. To examine the strength of IBES, main data was collected namely students' achievement and perception. Students' achievement was measured by the multiple choices questions sheet, while students' perception data was gathered by the questionnaire sheet. The result shows that students' achievement mean score in experimental group was 75.7 which is higher than control group that its mean score was 58.73. Students' perception result showed that more than $70 \%$ students have positive responses toward the IBES in all aspects including curiosity, inquiry skills, teamwork attitudes, collaborations, interdependence, and communication skills. The challenges of IBES are the diversity of students' background, the lack of curiosity, the lack of prior knowledge, the lack of confidence, and the lack of communication skills. Some recommendations for the effectiveness of implementation of IBES will be given.

Keywords: inquiry-based learning, active learning, expertise, knowledge sharing, graduate employability, education, Indonesia. 


\section{MALAYSIAN ONLINE JOURNAL OF EDUCATIONAL MANAGEMENT (MOJEM)}

\section{INTRODUCTION}

The emerging advanced technology such as artificial intelligence, robotics, the Internet of Things, and big data has generated fourth industrial revolution (Kaeser, 2018). It not only increases the efficiency and pleasure of our personal lives, but also disrupts job market (Howell \& Schwab, 2018). Robotics and artificial intelligence have shifted human labours, which have caused many workers lose their jobs and threaten other workforces (Martens \& Tolan, 2018). Governments and employer's demand for highly-skilled workers increases to face new challenges, opportunities, or risks emerged by such revolution (Durazzi, 2018).

To respond to new labour market demands, higher education institutions have enhanced employability of graduates, regarded it as one of central institution tasks (Bridgstock, 2016b) and even enacted it as a new institution mission (Suleman, 2018). Employability is defined as being capable of getting and keeping fulfilling work (Hillage \& Pollard, 1998), and essential as an alternative to job security (Bernstrøm, Drange, \& Mamelund, 2019). Employability has been made as performance indicator (Morley, 2002) or aspect of quality of higher education (Støren \& Aamodt, 2010). Employability is constructed as a matter of an individual's skills (Moreau \& Leathwood, 2006). Generally, there are two categories of employability skills: discipline-specific skills and knowledge, and generic/transferable skills (Clanchy \& Ballard, 1995).

Surveys toward employers show that more than disciplinary knowledge and skills is needed to be successful in recent labour market (Wolff \& Booth, 2018). Some generic/transferable skills are essential factors for adapting in changing job market. Generic skills have been intended to higher education graduates which commonly are stated as generic graduate's attributes which are variously defined by different universities (Barrie, 2006). Generally, those skills defined as a mix of skills components, attitudes, values, and disposition (Hager, Holland \& Beckett, 2002).

There are two types of effort to enhance graduate employability in higher education namely internal reinforcement programs such as career management skills (Bridgstock, 2009) and external collaboration such as work-integrated learning (Cooper, Orrell, \& Bowden, 2010). Nevertheless, internal reinforcement programs by a revolution of teaching and learning in the classroom is still fundamental effort as a main focus of universities (Bridgstock, 2016b). It is not new idea that learning process in higher education should foster students to more actively learn to develop their knowledge and skills (Bonwell \& Eison, 1991). Active learning could be made by more flexible teacher-student relationship (Frymier \& Houser, 2000) or interaction among students (LaBelle \& Johnson, 2018).

Indonesian higher education institutions have implemented active learning programs in Higher Education (ALIHE) to enhance their learning quality. There have been various learning models that were applied to improve students' competences such as cooperative learning, inquiry-based learning, discovery learning, project-based learning, or problem-based learning. However, some research show that the implementation of such models are still oriented towards student learning outcomes in disciplinary fields, not to develop all generic skills demanded by the workplaces in the 21st century. For example, Cooperative Integrated Reading and Comprehension (CIRC) model was implemented in biology course to improve only academic achievement (Ristanto, Zubaidah, Amin, \& Rohman 2018). Indeed, some models were also implemented to improve generic skills, but it was only for certain generic skills. Husamah (2015) reports that Blended Project-Based Learning model was able to improve students' thinking skills including self-regulated thinking, critical thinking, and creative thinking. Ana and Achdiani (2015) also report that Internet-Based Self-regulated Learning was also able to enhance students' self-regulated learning skills. Whereas, various and comprehensive generic skills and personal attributes tend to be trained in extracurricular programs. Although these programs are effective in increasing students' generic skills (Nugraha, 2016), it is not all students are involved in such programs. Therefore, students do not have the same opportunity to develop their generic skills and personal attributes. So far there has not been a comprehensive learning model oriented to 


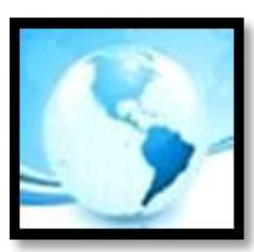

\section{MALAYSIAN ONLINE JOURNAL OF EDUCATIONAL MANAGEMENT (MOJEM)}

mastering course content as well as developing generic skills and personal attributes in a whole learning process that can be followed by all students.

The researchers propose one of innovative learning models named Inquiry-Based Expertise Sharing (IBES) as comprehensive learning strategy to improve employability of graduates, both disciplinary skills and knowledge, and generic/transferable skills. In this model, the researchers combine and integrate Jigsaw method (Aronson, 1978; Slavin, 1986), Inquiry-Based Learning (Pedaste et al., 2015), and knowledge sharing to facilitate students for mastering disciplinary knowledge as main emphasis, as well as fostering generic skills as additional outcomes. The researchers then empirically tested it in higher education classroom. The researchers propose some research questions that will be discussion in this paper based on findings from such empirical test. The questions are the followings:

1. What are the strengths of IBES concerning the graduate employability, both disciplinary knowledge and generic/transferable skills, which are found by empirical test?

2. What are the challenges of IBES identified by empirical test to determine some resolving strategies to get more effective implementation?

3. What are the proposed recommendations to make the implementation of IBES to be more effective in broader contexts?

\section{THEORETICAL FOUNDATION}

\section{Jigsaw}

Jigsaw was initially proposed by Aronson and Bridgeman (1979) to desegregate classroom for prompting interdependence attitude among diversity of students. In original Jigsaw, students are divided into groups which have five or six members. Each student in a group has one and only one segment of written material. Each student has a unique and vital part of the information that must be learn and teach it to the other members of group. Each student spends part of her time in the role of expert. The method was named jigsaw because it is similar to the pieces of the jigsaw puzzle, with each part of learning material has to be put together in order to learn the whole picture of the material.

Because of a weakness in original Jigsaw, Slavin (1986) then modified it and proposed Jigsaw II. In the original Jigsaw, each student gets a different part material and does not know other parts. This is difficult to be applied because books usually can be not simply separated into some parts. Slavin modified this condition by using worksheets containing all material which makes each student knows whole material and then focuses to certain part as his/her expertise. In Jigsaw II, Slavin also adds quiz in the end of expert section which is not in original Jigsaw.

At the beginning of its appearance, Jigsaw was developed to reform learning process in lower level education, such as elementary and secondary schools. But, some recent research reports that Jigsaw I is also effective in higher education. Weidman and Bishop (2009) reported the use of Jigsaw for online learning appears four characteristics of cooperative learning including development social skills, interdependence, individual accountability, and promotive interaction. Jigsaw is also effective in medical education, especially for improving technical and nontechnical management skills (Fryman, Fei, Mehta, \& Ahmad, 2018). Meanwhile, Liao, Griswold, and Porter (2018) reported most students in computing education have good perception toward Jigsaw. Students thought the Jigsaw activities helped their learning.

Nevertheless, the implementation of Jigsaw requires a longer time compared to other cooperative models. This is because Jigsaw has two main stages that are equally important for achieving overall learning goals, namely mastering expertise and sharing expertise (Slavin, 1986). Although it takes a lot of time, students' learning 


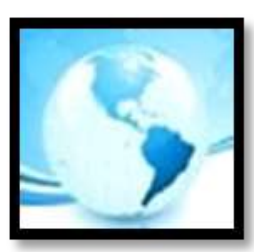

\section{MALAYSIAN ONLINE JOURNAL OF EDUCATIONAL MANAGEMENT (MOJEM)}

outcomes especially mastery of concepts are sometimes still lower than other cooperative learning strategies (Johnson, Johnson, \& Stanne, 2000). Such condition could be overcome by inserting new strategies especially for mastering concepts and sharing expertise.

\section{Inquiry-Based Learning (IBL)}

Inquiry-Based Learning (IBL) can be inserted to Jigsaw to overcome its weakness especially in mastering expertise. Hmelo-Silver, Duncan, and Chinn (2007) present evidence that show that inquiry learning is powerful and effective model of learning especially in mastering content knowledge, epistemic practices, and soft skills such as collaboration and self-directed learning. Inquiry-based learning has been being used in some higher education institutions especially in science courses which show that it is effective to improve science literacy and research skills (Brickman, Gormally, Armstrong, \& Hallar, 2009).

Pedaste et al. (2015) have examined 32 different forms of inquiry-based learning and concluded that it has five main phases including orientation, conceptualization, investigation, conclusion, and discussion. Based on their overview, Pedaste et al. (2015) develop a new framework. The framework presents general phases, sub-phases, and their relations. Four phases are ordered systematically, namely orientation, conceptualization, investigation, and conclusion. Meanwhile, discussion phase is linked to all other phases. Conceptualization, have two sub-phases: questioning and hypothesis generation. Investigation involves three sub-phases: exploration, experimentation, and data interpretation. Meanwhile, discussion includes two sub-phases namely communication and reflection.

\section{Knowledge Sharing}

To avoid discussion within home groups in Jigsaw becoming boring, some methods of sharing knowledge should be developed. Although some researchers uses interchangeably knowledge sharing and knowledge exchange, Wang and Noe (2010) argue that the both are different. They describe that knowledge sharing is only to provide knowledge to others, while knowledge exchange is combination of both knowledge sharing and knowledge seeking (to search knowledge from others). In this study, the researchers use the term knowledge sharing including knowledge exchange as well, which someone not only shares his knowledge to others, but also seeks and gets knowledge from others.

\section{METHOD}

\section{Research Design}

This study used a mixed-modes research design as suggested by Reswell (2013) for combination of qualitative and quantitative methods. There were two phases of research namely developing a pilot project and conducting experimental testing. Qualitative method was implemented through develop a pilot project. Meanwhile, quantitative method was conducted to test the effect of framework toward students learning. In first phase, an initial comprehensive learning framework was developed as pilot project. Jigsaw method, Inquiry-Based Learning, and Knowledge Sharing were combined and integrated to be one framework named as Inquiry-Based Learning and Knowledge Sharing (IBES) (presented in Figure 1). There were five stages in this framework including orientation, formulating questions, mastering expertise, sharing expertise, and assessment and reflection. Aronson's idea about Jigsaw (Aronson, 1978) and its modification by Slavin (Slavin, 1986) was used in whole of model. Then, some stages of Jigsaw were modified by inserting IBL as method of discussion within expert group and knowledge sharing as method of sharing expertise. 


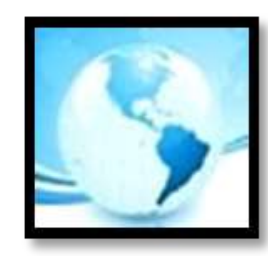

MALAYSIAN ONLINE JOURNAL OF

EDUCATIONAL MANAGEMENT

(MOJEM)

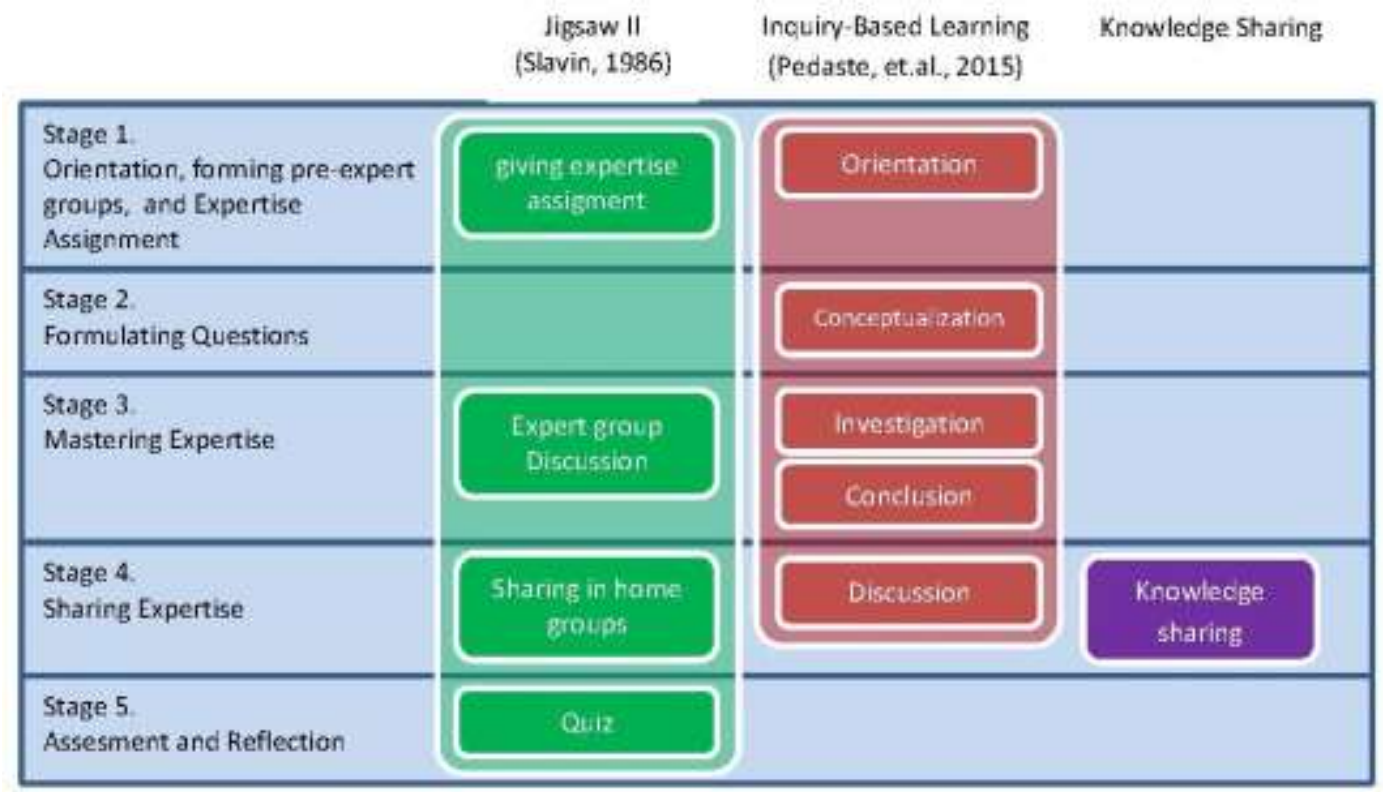

Figure 1. Inquiry-Based Expertise Sharing Model Framework

In this framework, the course was divided in some parts, topics, or sections and then spread divided parts onto different groups. Learning materials was packaged into parallel instead of serial type (see Figure 2 ) in order so that each expert group could independently mastery their expertise. Different groups were named as pre-expert group, because its members had not been experts but forerunners of experts. The number of pre-expert groups depended on the number of divided topics or sections.

Each pre-expert group was prompted to learn their section and to be expert in such section. Each pre-expert group learnt expertise topic to become an expert in such topic through Inquiry-Based Learning, a framework which is developed by Pedaste et al. (2015). Mastering expertise in this model was slightly different from Jigsaw method. Jigsaw only uses discussion method to facilitate each expert group to master their part. Whereas, expert groups in this model were prompted to investigate their expertise topics through comprehensive and systematic investigation method by using IBL framework. Each different expert shared reciprocally their expertise to other different experts and got something from others as well. In this model, each expert did not share their knowledge in home group like in original Jigsaw (Aronson, 1978) and Jigsaw II (Slavin, 1986). Each expert shared their information and knowledge to anyone who was interested and needed by using some knowledge sharing methods. 

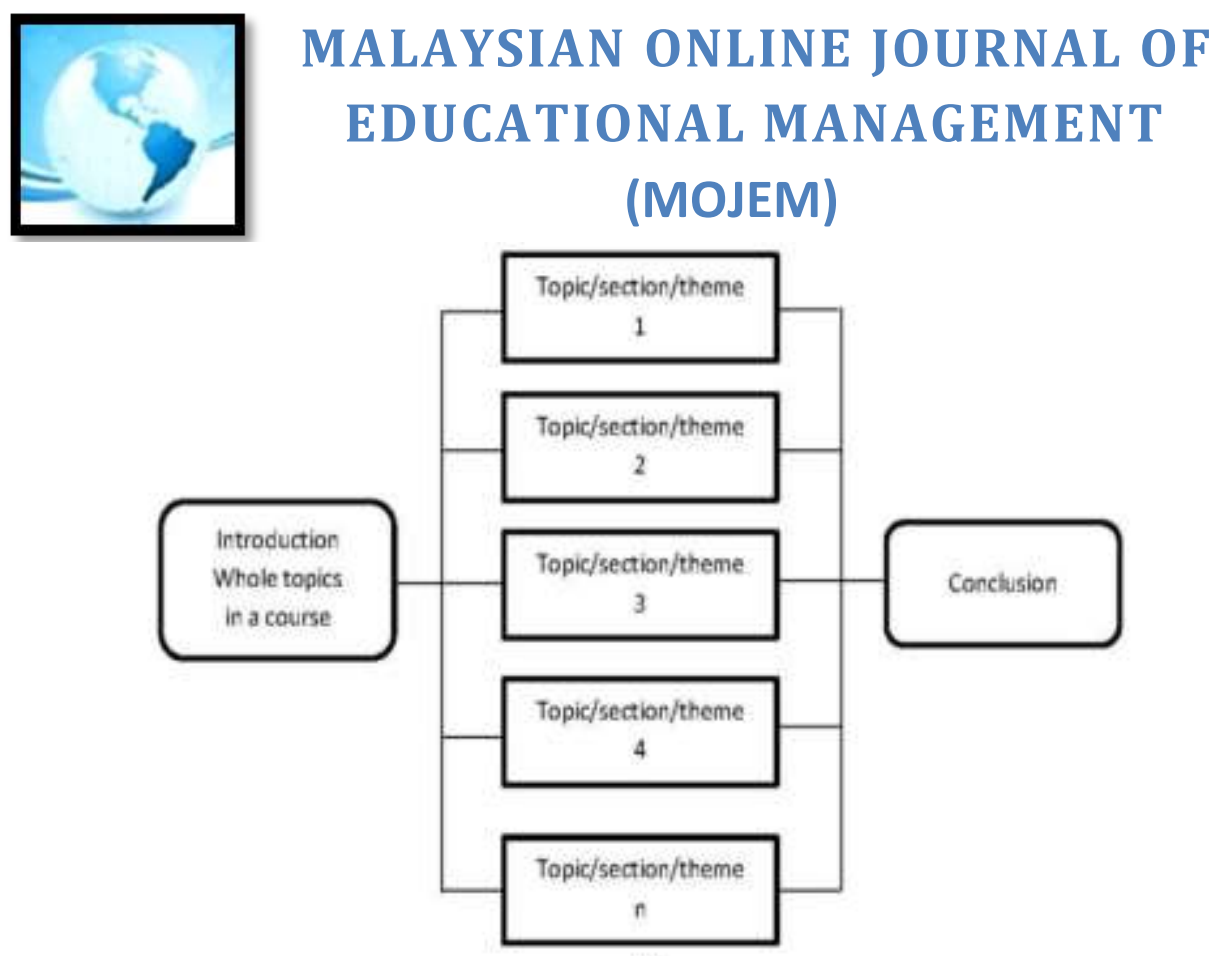

(a)
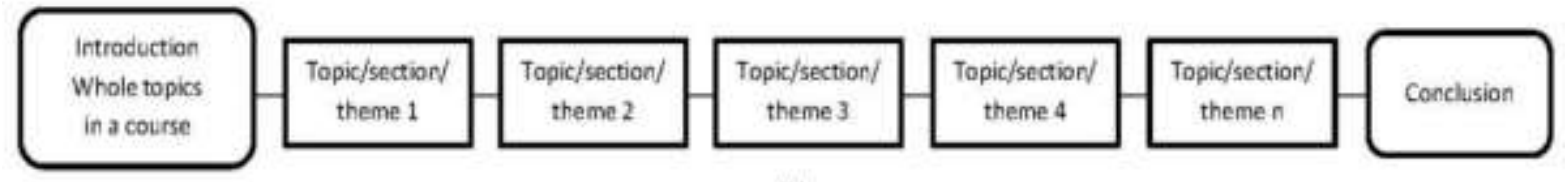

(b)

Figure 2. Parallel (a) versus Serial Model (b) in Packaging Materials

The initial framework was empirically tested in the first phase to examine its effectiveness and weakness. This was conducted in the second semester in 2018. The framework was implemented to the basic concepts of life science course. The course was packaged into nine big themes namely organization of life, ecosystem, biodiversity, chemistry of life, life cycle, plants anatomy and physiology, animal anatomy and physiology, human anatomy and physiology, and genetics. Those themes were expertise topics that were given to each pre-expert group. They then independently learned each theme to mastery it. Each different group member shared their expertise to others by using pair sharing group and presentation in small group.

Qualitative data was collected throughout the implementation of initial IBES framework. Based on analysed data, the framework was revised, modified and formulated into the new stages of the IBES (see Figures 2). There was one addition stage in the revised model which make it had six stages. The addition stage was expertise confirmation which was placed as fourth stage. The last stage of IBES was also revised by changing evaluation and reflection with appraisal and reward. Reward and punishment were implemented in this stage based on students' learning achievements.

In the second phase, the revised IBES was experimentally tested in the same course but different students. This was conducted in the second semester in 2019. Quasi-experiment was used as research method. The research design was the Matching only Pre-Test Post-Test Control Group Design. In this design, there were two sample groups involved, control and experiment group. Control group was given learning experience using cooperative learning. Meanwhile, experiment group got experience with IBES as the treatment. Student's achievement for both of the groups were then compared in order to examine the effect of IBES to student learning. 


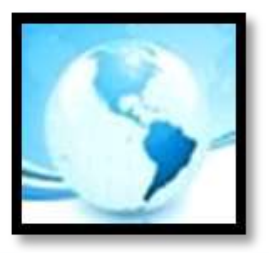

\section{MALAYSIAN ONLINE JOURNAL OF EDUCATIONAL MANAGEMENT (MOJEM)}

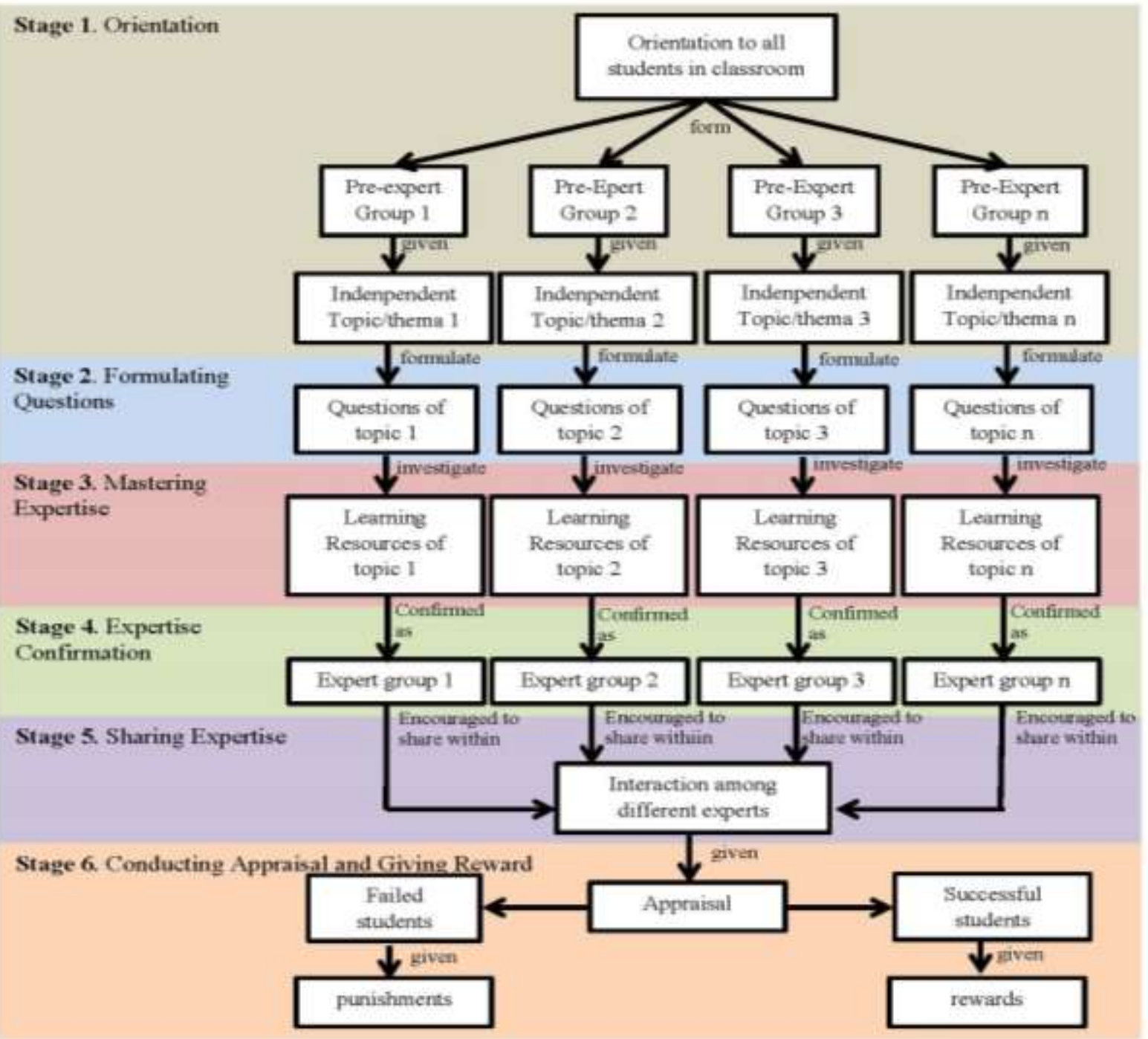

Figure 3. The revised Framework of IBES

\section{Population and Sampling}

Both of research phases involved the third-year students in Elementary School Teacher Education Program. They had different educational background such as science, social sciences, and various vocational fields in secondary high school. They were required to mastery disciplinary knowledge and skills in education field as well as generic/transferable skills. In the first phase, one group among three student groups in academic year 2018 was involved as research samples. The sample group contained 40 students. Meanwhile in the second phase, two groups of students in academic year 2019 were chose as research samples. Each group contained 40 students. One group was selected as control group while another was selected as experimental group. Selecting sample groups in the both of phases used cluster random sampling technique. 


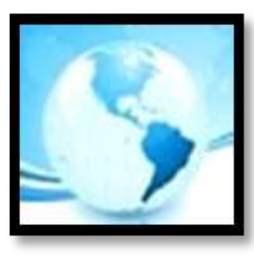

\section{Instrumentations}

There were qualitative and quantitative data that were collected. Qualitative data was obtained by researchers as main instrument. Researchers used observation guide to collect data about learning process. The result of observations was written in daily journal. Researchers also used the list of open questions to interview some samples. The questions were about students' feeling, difficulties, problems, and suggestions.

Quantitative data was students' achievement and perception toward IBES. Students' achievement was measured by written test using multiple choices questions sheet. The instrument was a standard test that had been validated and standardized by institution. There were a hundred questions and four choices in this sheet. Meanwhile, students' perception toward IBES was measured by questionnaire sheet. The questionnaire was Likert Scale with five responses including strongly agree, agree, neutral, disagree, and strongly disagree. There were 30 developed statements which were stated in Indonesian and then translated to English in this article. All statements were evaluated to get validity and reliability.

\section{Quantitative Data Collection and Analysis}

The multiple choices test instrument was given twice to both of groups. The first test was conducted in the beginning meeting, while the second was given in the last meeting. The both of tests were conducted in the classroom along ninety minutes. Meanwhile, the questionnaire was given only to experimental group in the last meeting. Researchers shared file of questionnaire in social media WhatsApp group. Each student gave response by their private numbers. Students' response about learning was also collected by interview. Some open questions were given by social media WhatsApp group. Each student was allowed to give some responses by such group or personal chatting.

Students' achievement and perception was statistically analysed. Descriptive statistics for students' achievement including mean, standard deviation, and variance in both of groups were calculated. Normality and homogeneity of data in both of group were also calculated to determine which inferential statistics that would be used. Normality of data was calculated by using Kolmogorov-Smirnov test, while homogeneity was calculated by using Levine test. Because data were normal and homogeny, parametric inferential statistics was used namely t-test. Meanwhile, students' perception was analysed by using descriptive statistics namely percentage. Students' responses were analysed by using content analysis technique. All statistic components were analysed by using SPSS program.

\section{Qualitative Data Collection and Analysis}

The researchers collected and analysed qualitative data in the same time as suggested by Miles, Huberman, and Saldana (2014). There were four phases of qualitative data analysis namely data collecting, condensing, validating, and concluding. The four phases were conducted in the same time throughout research process. Qualitative data especially about students' activities, interactions, statements, and feeling were obtained through observation, interview, and documentation. The data was then condensed to get information about the challenges of implementation of IBES. Later on, the data was validated using triangulation method.

\section{Validity and Reliability}

The validity and reliability of qualitative data were confirmed by triangulation of sources and methods. In triangulation of sources, data from different sources were compared to get more valid data. For example, data from a respondent were compared to other strongly related respondents such as his friends to check whether they gave similar information or not. When the information was identic, data could be concluded valid and reliable. In triangulation of methods, data from different methods such as observation, interview, and documentation were compared to get more valid data. For example, data from observation were confirmed by interview to involved 


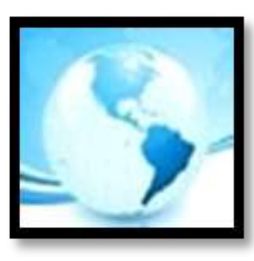

\section{MALAYSIAN ONLINE JOURNAL OF EDUCATIONAL MANAGEMENT (MOJEM)}

respondents. Their statements were also compared to relevant documents such as educational background documents. When information from such different methods had identic attributes, data were concluded valid and reliable.

The multiple choices questions sheet was not validated because it was standard instrument which was validated by institution. The instrument had Cronbach's alpha of reliability coefficient 0.781 . Meanwhile, the questionnaire was validated by an expert and tested by empirical testing. Testing was conducted in another group in similar academic year with research samples. The validity of each item of statement was evaluated by Pearson's Correlation Coefficient. The coefficient of each item was compared to minimum coefficient value 0.3 . The result showed that 22 of 30 items were valid (see Table 1). The reliability of the questionnaire was evaluated by means of Cronbach's alpha of reliability coefficient $(\alpha)$. The result showed that the instrument had alpha 0.68 .

Table 1

The result of Pearson's Correlation Coefficient for each item of the questionnaire

\begin{tabular}{cccccc}
\hline $\begin{array}{c}\text { Number of } \\
\text { items }\end{array}$ & $\begin{array}{c}\text { Pearson's } \\
\text { Correlation } \\
\text { Coefficient }\end{array}$ & Conclusion & $\begin{array}{c}\text { Number of } \\
\text { items }\end{array}$ & $\begin{array}{c}\text { Pearson's } \\
\text { Correlation } \\
\text { Coefficient }\end{array}$ & Conclusion \\
\hline 1 & 0.432 & Valid & 16 & 0.544 & Valid \\
2 & 0.587 & Valid & 17 & 0.254 & Not valid \\
3 & 0.671 & Valid & 18 & 0.602 & Valid \\
4 & 0.287 & Not valid & 19 & 0.623 & Valid \\
5 & 0.398 & Valid & 20 & 0.579 & Valid valid \\
6 & 0.465 & Valid & 21 & 0.143 & Valid \\
7 & 0.202 & Not valid & 22 & 0.439 & Valid \\
8 & 0.671 & Valid & 23 & 0.476 & Valid \\
9 & 0.279 & Not valid & 24 & 0.689 & Valid \\
10 & 0.701 & Valid & 25 & 0.354 & Valid \\
11 & 0.087 & Valid & 26 & 0.491 & Not valid \\
12 & 0.512 & Valid & 27 & 0.197 & Valid \\
13 & 0.543 & Valid & 28 & 0.541 & Valid \\
14 & 0.195 & Not valid & 29 & 0.651 & Valid \\
\hline
\end{tabular}

\section{RESULTS}

\section{Sample Demographics}

Demographics of sample in both of groups were as shown in Table 2. There were 80 students involved in experimental testing of IBES model. All students were grouped into control and experimental group. There were 40 students in each group. There were some variables of sample which were diverse in gender, educational background, major in high school, and financial support. The majority of sample in both group were originated from general high school, $90 \%$ in control group and $82.5 \%$ in experimental group. The others were from vocational high school and Islamic high school. Sample in both of groups was also dominated by science major, $67.5 \%$ in control group and $50 \%$ in experimental group, followed by social sciences, $30 \%$ in control group and $42.5 \%$ in experimental group. There were also vocational major in both of groups. In the control group, there were accounting (2.5\%), while in experimental group there were mechanical engineering (2.5\%), computer engineering (2.5\%), and administration (2.5\%). The majority of sample was financially supported by their family in the both of groups, $82.5 \%$ in control group and $90 \%$. The remains got scholarship. 


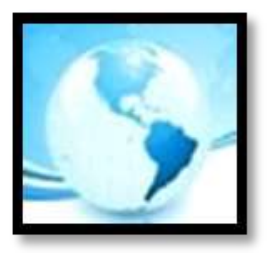

MALAYSIAN ONLINE JOURNAL OF

EDUCATIONAL MANAGEMENT

(MOJEM)

Table 2

Sample Demographics

\begin{tabular}{|c|c|c|c|c|}
\hline \multirow{2}{*}{ VARIABLE } & \multicolumn{2}{|c|}{ FREQUENCY } & \multicolumn{2}{|c|}{ PERCENTAGE (\%) } \\
\hline & CONTROL & EXPERIMENTAL & CONTROL & EXPERIMENTAL \\
\hline \multicolumn{5}{|l|}{ Gender } \\
\hline Male & 5 & 7 & 12,5 & 17,5 \\
\hline Female & 35 & 33 & 87,5 & 82,5 \\
\hline \multicolumn{5}{|l|}{ Educational Background } \\
\hline General High School & 36 & 33 & 90 & 82,5 \\
\hline Vocational High School & 1 & 3 & 2,5 & 7,5 \\
\hline Islamic High School & 3 & 4 & 7,5 & 10 \\
\hline \multicolumn{5}{|l|}{ Major In High School } \\
\hline Science & 27 & 20 & 67,5 & 50 \\
\hline Social Sciences & 12 & 17 & 30 & 42,5 \\
\hline Mechanical Engineering & 0 & 1 & 0 & 2,5 \\
\hline Computer Engineering & 0 & 1 & 0 & 2,5 \\
\hline Accounting & 1 & 0 & 2,5 & 0 \\
\hline Administration & 0 & 1 & 0 & 2,5 \\
\hline \multicolumn{5}{|l|}{ Financial Support } \\
\hline Family & 33 & 36 & 82,5 & 90 \\
\hline Scholarship & 7 & 4 & 17,5 & 10 \\
\hline
\end{tabular}

\section{The Strength of IBES}

The strength of IBES was showed by the quality of learning process and its result. The quality of the learning process is examined by measuring students' perceptions toward learning process of IBES that is associated with the development of various generic skills. The collected data was statistically analysed by calculating the percentage of each category of students' responses. There are five students' response categories toward statements about IBES learning process including strongly agree (SA), agree (A), neutral (N), disagree (D), and strongly disagree (SD). The sample who filled in the questionnaire was only students in experimental group who experienced learning process of IBES. The percentage of each student response category is presented in Table 3.

Based on Table 3, it is known that the majority of students gave positive responses to each statement item. There are more than $70 \%$ of students who agree and strongly agree with each statement. In fact there are four statement items whose percentage of positive responses are more than $90 \%$, namely item 2, 13, 16 and 22 . In addition there are 3 statement items whose responses strongly agree more than $50 \%$ namely items 5, 8, and 13 . The highest of percentage for neutral response is $22.22 \%$ in item 4 . There are not students who disagree or strongly disagree to all statements. 


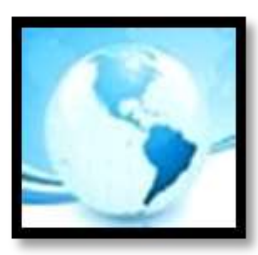

MALAYSIAN ONLINE JOURNAL OF

EDUCATIONAL MANAGEMENT

(MOJEM)

Table 3

Students' Perception toward IBES

\begin{tabular}{|c|c|c|c|c|c|c|}
\hline \multirow{2}{*}{ No } & \multirow{2}{*}{ STATEMENTS } & \multicolumn{5}{|c|}{ PERCENTAGE } \\
\hline & & SA & A & $\mathbf{N}$ & D & SD \\
\hline 1 & $\begin{array}{l}\text { IBES gave me the opportunity to interact more } \\
\text { independently to lecturer }\end{array}$ & 25 & 66.67 & 8.33 & 0 & 0 \\
\hline 2 & $\begin{array}{l}\text { IBES enable to make my interactions with lecturer more } \\
\text { effective and interactive }\end{array}$ & 5.56 & 88.89 & 5.56 & 0 & 0 \\
\hline 3 & $\begin{array}{l}\text { IBES makes me more comfortable when I interacted with } \\
\text { lecturer }\end{array}$ & 22.22 & 61.11 & 16.67 & 0 & 0 \\
\hline 4 & $\begin{array}{l}\text { Interaction with lecturers succeeded in helping me } \\
\text { overcome learning difficulties }\end{array}$ & 25 & 52.78 & 22.22 & 0 & 0 \\
\hline 5 & $\begin{array}{l}\text { IBES was able to encourage me to interact effectively and } \\
\text { interactively with my classmates }\end{array}$ & 52.78 & 30.56 & 16.67 & 0 & 0 \\
\hline 6 & $\begin{array}{l}\text { I like learning that encourages me to interact with my } \\
\text { classmates. }\end{array}$ & 44.44 & 30.56 & 25 & 0 & 0 \\
\hline 7 & IBES enable to increase my curiosity. & 30.56 & 58.33 & 11.11 & 0 & 0 \\
\hline 8 & $\begin{array}{l}\text { IBES enable to increase my awareness that learning should } \\
\text { be started from my own curiosity. }\end{array}$ & 52.78 & 30.56 & 16.67 & 0 & 0 \\
\hline 9 & IBES enable to me to find out how to learn by inquiry. & 36.11 & 38.89 & 25 & 0 & 0 \\
\hline 10 & IBES was able to encourage me to learn by inquiry & 25 & 50 & 25 & 0 & 0 \\
\hline 11 & $\begin{array}{l}\text { The expert group enable to me to realize the importance of } \\
\text { teamwork to achieve greater results }\end{array}$ & 47.22 & 38.89 & 13.89 & 0 & 0 \\
\hline 12 & $\begin{array}{l}\text { The expert group was able to encourage me to work in a } \\
\text { team }\end{array}$ & 41.67 & 41.67 & 16.67 & 0 & 0 \\
\hline 13 & $\begin{array}{l}\text { Sharing expertise was able to make me to realize that my } \\
\text { classmates and I are interdependent. }\end{array}$ & 51.43 & 45.71 & 2.86 & 0 & 0 \\
\hline 14 & $\begin{array}{l}\text { Interdependence among students is very important to get } \\
\text { more benefit in learning. }\end{array}$ & 42.86 & 48.57 & 8.57 & 0 & 0 \\
\hline 15 & I like collaborative learning in expert group & 41.67 & 50 & 8.33 & 0 & 0 \\
\hline 16 & $\begin{array}{l}\text { Inquiry activities in expert group make me realize that } \\
\text { collaboration is important. }\end{array}$ & 37.14 & 57.14 & 5.72 & 0 & 0 \\
\hline 17 & $\begin{array}{l}\text { Inquiry activities in expert group were able to enhance my } \\
\text { collaboration skills. }\end{array}$ & 28.57 & 51.43 & 20 & 0 & 0 \\
\hline 18 & I like sharing expertise & 33.33 & 41.67 & 25 & 0 & 0 \\
\hline 19 & Sharing expertise is a fun learning activities & 27.78 & 47.22 & 25 & 0 & 0 \\
\hline 20 & $\begin{array}{l}\text { Mastery expertise in expert group was able to improve my } \\
\text { communication skills }\end{array}$ & 34.29 & 54.29 & 11.42 & 0 & 0 \\
\hline 21 & I like sharing expertise with various classmates & 42.86 & 45.71 & 11.43 & 0 & 0 \\
\hline 22 & $\begin{array}{l}\text { Sharing expertise activities enable to improve my } \\
\text { communication skills. }\end{array}$ & 42.86 & 54.29 & 2.86 & 0 & 0 \\
\hline
\end{tabular}

The strength of IBES was also examined by analysing the difference of students' achievement between control and experimental group. Before giving treatment in experimental group, prior knowledge of students in both groups was measured first at the beginning of learning by pre-test. After giving treatment in both groups, student achievement was measured by post-test. The results of the pre-test and post-test were statistically analysed which are presented in Table 4. 


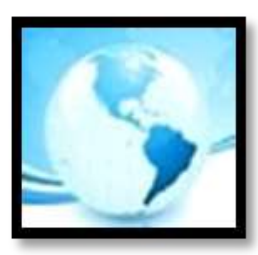

MALAYSIAN ONLINE JOURNAL OF

EDUCATIONAL MANAGEMENT

(MOJEM)

Table 4

The Result of Analysis toward Pre-test and Post-test in the Both of Groups

\begin{tabular}{ccccc}
\hline \multirow{2}{*}{$\begin{array}{c}\text { Statistically analysed } \\
\text { components }\end{array}$} & \multicolumn{2}{c}{ Pre-test } & \multicolumn{2}{c}{ Post-test } \\
\cline { 2 - 5 } & Control & Experimental & Control & Experimental \\
\hline Mean & 44.43 & 44.48 & 58.73 & 75.70 \\
Standard deviation & 5.804 & 6.465 & 8.566 & 10.737 \\
Variance & 33.687 & 41.794 & 73.384 & 115.292 \\
Normality & 0.106 sig=0.200 & 0.082 sig= 0.200 & 0.145 sig= 0.033 & 0.148 sig=0.027 \\
Homogeneity & \multicolumn{2}{c}{0.587 sig= 0.446} & 1.817 sig=0.182 \\
t-test & sig. (2-tailed) $=0.971$ & sig. (2-tailed) $=0.000$
\end{tabular}

Based on Table 4 above, it is known that the prior knowledge of students in the two groups did not differ significantly as indicated by the results of the test between the two groups. Significance value of t test is 0.971 which is higher than 0.05. Meanwhile, students' achievement in the both of groups differed significantly as indicated by the significance value of the t test of 0.000 . Students' achievement in the experimental group is higher than in the control group.

\section{The Challenges of IBES}

The challenges of IBES were examined by analysing both of quantitative and qualitative data.

Based on statistically analysis, there were seven students who not get minimal scores 70 of 100 . They then were chose to be respondents who were more deeply interviewed. They were asked about their difficulties and problems to attend learning activities and to mastery contents. Majority of them answered that they had difficulty in remembering terminology of the course because their background were not science, but social sciences. Those who had social sciences background felt less confident when they have to share their expertise to students who had Science background. Their statements were confirmed to their sharing partners to ensure that their statements were valid and reliable. Their statements were also compared to research notes of observation to confirm that those were consistent. Based on that information, the researchers concluded that the difference of previous educational backgrounds is one of the big challenges in implementing IBES.

Based on the interview to students who get lower scores, the researchers found that they had difficulties to investigate their sharing partners. They felt difficulty to formulate investigate questions. They did not know what questions should be asked to their partner. They could not make more deep questions. Their statements were confirmed to document about their list of investigative questions. Their statements were also compared to statements from their sharing partners. The result showed that their statement was consistent with their document and statement from their partners. Based on that result, the researchers concluded that formulating question skills is another challenge to make the implementation of IBES more effective.

Nevertheless, some of them also acknowledged that they were able to formulate more deeply questions to investigate different experts. Unfortunately, their partners were unable to more accurately and comprehensively answer. Therefore, they did not get sufficient information. Their statement was consistent with observation notes in daily journal that showed that there were some students who were unable to explain their expertise to their partners. Those who were unable to explain their expertise admitted that they did not mastery more deeply their expertise. It was consistent with their test results that showed that their scores were minimal. Based on such data, it can be concluded that the lack of mastery of content is big challenge in implementing this model. 


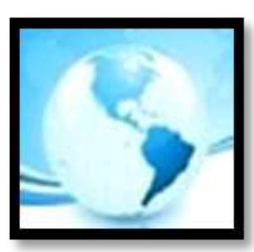

\section{MALAYSIAN ONLINE JOURNAL OF EDUCATIONAL MANAGEMENT (MOJEM)}

\section{The Recommendations for Effective Implementation of IBES}

Based on analysis toward the strength, the challenges, and other qualitative data, the researchers propose some recommendation to make the implementation of IBES more effective. In the study, the researchers used most simple method in the stage of expertise mastering namely literatures review. Actually, such stage can be carried out by using various methods. Therefore, the researchers recommend to other lecturers to conduct such stage through many investigation methods. Students can be urged to become experts by experimental activities in laboratory (Hofstein \& Lunetta, 2004; Tobin, 1990). They also can learn to become experts in outdoor environment (Maynard \& Waters, 2007) through field trips (Falk, 1983; Orion, 1993). Deciding appropriate mastering expertise method depends on some factors such as teaching goals, course characteristics, students' experiences, students' prior knowledge, learning facilities (such as laboratory, experiment tools, references, internet network, computers, gadgets et cetera), or learning environment (classroom, and natural or social environment).

The researchers also suggest that the stage of expertise sharing should be done with various methods. In the first phase, some students felt bored when they experienced same way in some meetings. After that, various strategies of expertise sharing were used in the second phase. The expertise sharing in the second phase was more effective than the first. Based on examination toward some relevant references, we identify five determining elements to form expertise sharing strategies in learning context of higher education: group size, channel, method, media, and environment. Each element has some variations or sub-elements. The researchers propose knowledge sharing framework based on those elements and its sub-elements as presented in Figure 4. Teacher can combine subelements from each element to form certain expertise sharing strategy. These combinations produce many variations of strategies. For example, pair students can share their expertise by direct face to face using barter/exchange method without media in the classroom (showed by arrows in the Figure 4). If teacher changes one sub-element, then it will form different sharing strategy. The good strategy is the group of sharing that able to motivate all members to share and prevent free riders.

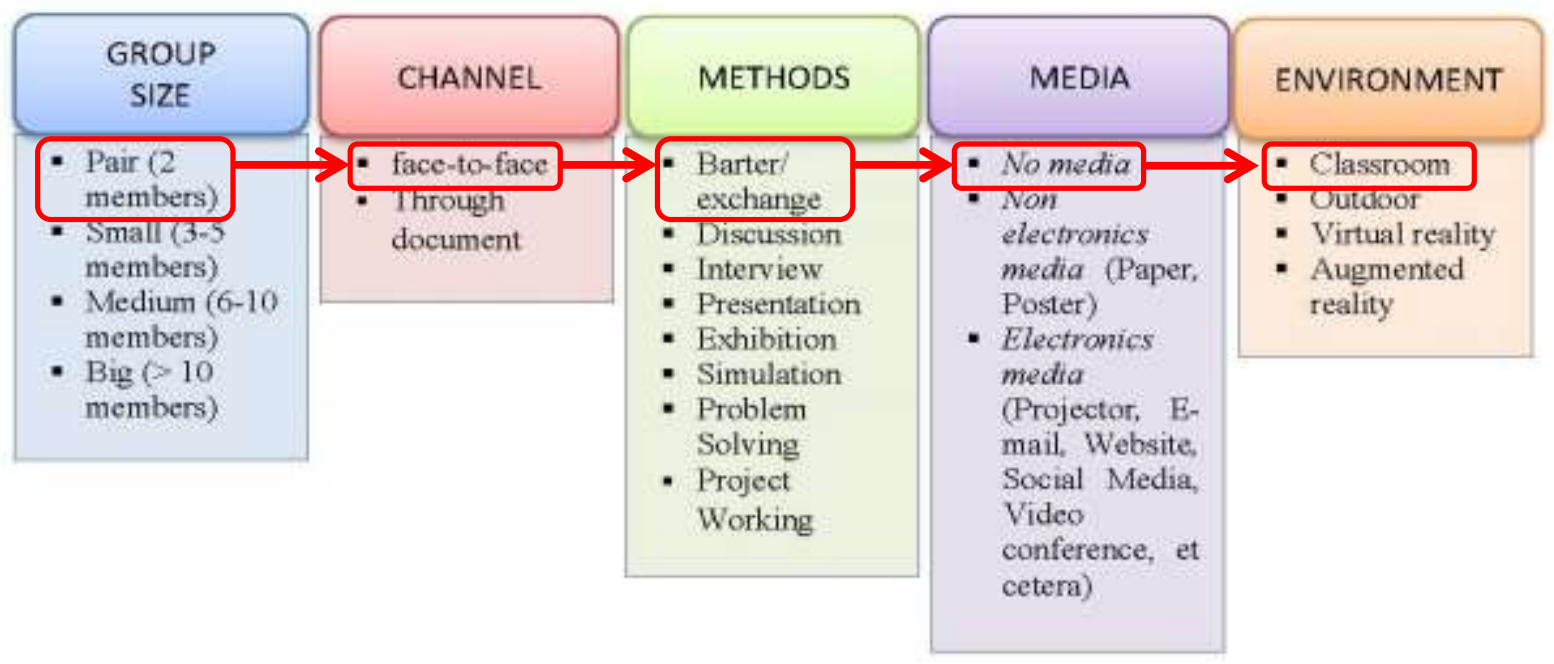

Figure 4. Knowledge Sharing Framework 


\section{MALAYSIAN ONLINE JOURNAL OF EDUCATIONAL MANAGEMENT (MOJEM)}

\section{DISCUSSION}

The researchers argued that the IBES provides great opportunities for students to master the subject matter knowledge by doing more effective interactions between teacher and students or among students through various methods. Based on Table 2, there are more students who both strongly agree and agree that IBES enable to encourage them to interact effectively and interactively with their lecturer and classmates. LaBelle and Johnson (2018) reported that interaction between student-student in classroom is valuable because it consist three messages: acknowledgement, assistance, and individual attention. Interview result confirm that interaction between student-student along mastering and sharing expertise stages improves individual attention, and helps some students to resolve their difficulties in learning.

This study also confirmed that IBES can foster many components of generic skills as a part of graduate employability needed in 21st century. The IBES is able to encourage students to have self-directed learning skills and to become independent lifelong learners. The ninth and tenth items in Table 2 show that more students who strongly agree and agree that IBES enable to encourage them to learn through inquiry by themselves. Self-directed learning skills are essential employability of graduates to enter modern organizations or workplaces (Bridgstock, 2016a). Bolhuis (2003) proposed that there are three interacting aspects of self-directed learning including learning to learn, knowledge base, and motivation. Our empirical test showed that the IBES gave experiences to develop all these three interacting aspects. Inquiry learning process in the IBES was representation of learning to learn. Table 2 show that more students acknowledged that IBES was encouraged them to identify their disciplinary knowledge and to examine and to access it to mastery their expertise. Seventh and eighth items in Table 2 also show that IBES make students learn based on their curiosity which would make them more motivated.

The research also confirms that IBES is able to make students to realize the important of teamwork, collaboration, and interdependence (showed by eleventh to seventeenth items in Table 2). Teamwork is crucial component in organizations to reach their goals (Salas, Shuffler, Thayer, Bedwell, \& Lazzara, 2015). Efficient and effective teamwork is the recommended approach to achieve and maintain a successful business (Conti \& Kleiner, 1997). Collaboration is also essential in advanced companies in facing the wave of global mergers, acquisitions and strategic alliances, plus the development of global networks (Child, 2001). Collaboration can lead to positive sum gains in internal activities and offer greater flexibility and effectiveness (Dodgson, 1993). Meanwhile, social interdependence is very needed to create effective collaboration within teamwork in workplaces (Tarricone \& Luca, 2002). Table 2 also show that expertise sharing activities in the IBES not only make students mastery disciplinary knowledge, but also urge them to work effectively and collaboratively within a team, and to interact interdependently among other members or other different expert groups.

The twentieth and twenty second items in Table 2 show that IBES enable and facilitate students to improve their verbal communication skills. Lee and Al-Hawamdeh (2002) argue that communication skill is one of the factors influencing effectiveness of knowledge sharing in organizations. Voogt and Roblin (2012) also state that effective verbal communication skill is one of global competences highly needed in the twenty first century. Table 2 shows that more students acknowledge that expertise sharing activities, especially pair knowledge exchange, have been successful to prompt student-student interaction to be more active and interactive. Observation results shows that those activities made all students to speak as well as to listen reciprocally. Direct experience in speaking and listening were effective method to improve verbal communication skills. Berkhof, van Rijssen, Schellart, Anema, and van der Beek (2011) found that direct experiences is the most effective method to improve communication skills.

This research also confirms that IBES is better than cooperative learning in increasing students' outcome. Experimental testing has confirmed that students' achievement in IBES learning is higher than in cooperative learning. Table 3 shows that students in the both of groups had similar knowledge before they learnt. After they learnt, students in experimental group who learn within IBES get higher mean score namely 75.7 than students 


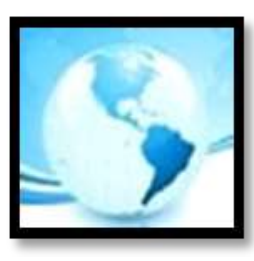

\section{MALAYSIAN ONLINE JOURNAL OF EDUCATIONAL MANAGEMENT (MOJEM)}

who learn within cooperative learning in control group which got mean score 58.73. It confirms that IBES is better strategy than cooperative learning to enhance the mastery of disciplinary knowledge. This finding confirms that interaction between lecturer and students, and interaction among students in the IBES are more effective than in the cooperative learning in increasing students' outcome.

The strengths of IBES above possibly because the IBES is combination of three integrated models which are not had in each model. Indeed, Jigsaw has strengths especially in improving social skills and attitudes which likely is found by Weidman and Bishop (2009) and confirmed by this our study, but it doesn't foster independent learning skills. This weakness has been covered by the IBL model, through the process of inquiry. The inquiry process can improve learning skills on how to learn both individually and in groups as confirmed by this research. Various knowledge sharing methods also make learning process mare comfortable and not boring.

This research also found that the IBES had some challenges to be overcome to effectively implement it. Diversity of student's educational background was the biggest challenge in implementing the IBES in the classroom. Our students were not only from science major in secondary high schools, but also from social sciences, or various vocational backgrounds. Such diversity made students facing difficulties in formulation of questions about science, mastering topics, as well as sharing their expertise because they did not have sufficient prior knowledge and experience in science learning. This condition should be a major concern for teachers or lecturers in implementing the IBES in their classrooms.

In the first phase, the researchers found that students who have non-science background faced difficulties in formulating relevant questions whereas it is fundamental competence to carry on inquiry activities (Booth, 2006). The lack of formulating question ability had been barrier to implement effectively the IBES. Implementation of the IBES still was not effective because some students could not formulate appropriate questions. This condition affected negatively further learning stages. Students who had inability in formulating questions also possibly did not have internal motivation, then faced difficulties to mastery their topics, and could not become perfect experts.

The result of this study also showed that there was the gap in mastery of topics among expert group members. There were some students who could not completely master knowledge in their topics. The lack mastery of knowledge had negative impacts on the entire learning process, especially at the expertise sharing stage. Students who had lack mastery of material on their expertise topic became less effective in sharing with their partners. This became serious problems for other students who expected to get complete and precise information from the expert students. This condition might be caused by the minor prior knowledge of students who had the education background not science. Prior knowledge relates to interest, which may have an energizing effect on learning and lead students to use deep comprehension processes (Tobias, 1994). Lecturers have to give more attention to diverse of students' educational background to make the implementation of IBES more effective.

The researchers also found that there was difference in verbal communication skills among students. This also had a negative impact on the low effectiveness of the stage of expertise sharing. Communication skills is primarily importance in knowledge sharing (Lee \& Al-Hawamdeh, 2002). Students who had low communication skills felt difficult to explain the material to other students. This made other students who needed knowledge from these experts felt disappointed because they did not get sufficient information to master the subject matter. This challenge has to overcome by lecturers to make learning process more effective.

The lack of mastery of content by each expert group member was another main problem that made sharing activities ineffective. Therefore, mastery of expertise has to be confirmed first by the authorities before learning process is continued to next stages. The researchers add confirmation stage in the revised framework to check mastery of contents and communication skills of each expert group member. Confirmation is needed to find out whether each member of the expert group has mastered the minimum standards of expertise and communication skills. Confirmation can be done within learning process through interaction between teacher-students. Some 


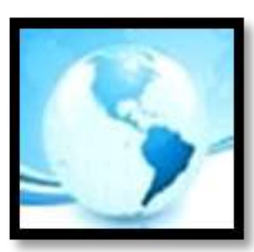

\section{MALAYSIAN ONLINE JOURNAL OF EDUCATIONAL MANAGEMENT (MOJEM)}

research have proven that teacher confirmation is an effective teaching behaviour in the classroom because it can enhance students learning (Goldman, Claus, \& Goodboy, 2018). Confirmation can also make students emotionally be better (Goldman \& Goodboy, 2014). Confirmation is important in communication because it could change students' behaviours and improve their verbal communication skills (Burns, Houser, \& Farris, 2017). Mastery of expertise, good emotion, good behaviour, and sufficient verbal communication skills are significantly needed to ensure that the sharing session in the IBES will take place more effectively and smoothly.

\section{IMPLICATIONS}

In term of theory, this study contributes to learning theory field, especially experiential learning which states that providing direct experiences to students is very important in student learning. This research provides the new framework of learning model which is able to give many experiences for students to improve their knowledge, attitudes and skills. This framework can inspire more research in experiential learning theory field that will expand its area.

In term of practice, the results of this study can change learning climate in the classrooms to enhance the quality of higher education. This model provides various experiences for students to empower their potential in order to match to $21^{\text {st }}$ century demands. Students will be more active and interactive using this model. These can change the interaction pattern in higher education classroom; not only interaction between lecturer and students, but also interaction among students themselves. Lecturers and students have to prepare themselves to adapt with such changes.

This model also has an implication to lecturers' roles throughout learning process. To implement this model more effectively, lecturers should not become the only one of learning resources who presents course materials in front of students. They have to enact role as leaders who generate and motivate students to learn. They should explain to students about why students have to learn the course, what its benefits, et cetera. They have to also act as managers who manage various learning activities such as questioning, investigation, discussion, presentation, sharing, communication, et cetera into systematic and comprehensive learning process. They have to be facilitators who facilitate students with learning sources. They have to show about how to learn effectively, how to communicate to others, which trustworthy learning resources, how to access such resources, how to criticize and check validity of such resources, et cetera.

\section{CONCLUSION AND RECOMMENDATION}

The researchers confidently conclude that the IBES is a comprehensive active learning model in higher education. It is comprehensive because it not only can improve mastery of disciplinary knowledge, but also foster many transferable/generic skills. In addition, along its learning process, students are always encouraged to do many activities using various methods which would activate simultaneously their body, senses, and mind. Furthermore, some challenges require attention by teachers or lecturers in order to increase effectiveness of IBES. Such challenges are the diversity of students' background, the lack of curiosity, the lack of prior knowledge, the lack of confidence, and the lack of communication skills. To make the implementation of IBES more effective, lecturers should use various investigation methods and various knowledge sharing methods.

Future projects can be carried on to examine and test this model in different contexts or conditions, included nonscience courses. Integration the IBES with advanced technology is also needed to be explored in further studies. IBES can also be integrated to project-based learning to make learning more meaningful. 


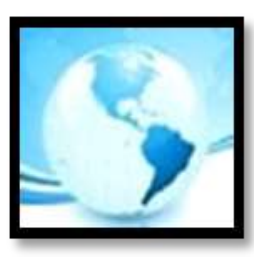

\section{REFERENCES}

Ana, A., \& Achdiani, Y. (2015). Penerapan Self Regulated Learning Berbasis Internet Untuk Meningkatkan Kemandirian Belajar Mahasiswa [Implementation of internet-based self regulated learning to increase student learning independence]. Innovation of Vocational Technology Education, 11(1), 15-22. https://doi.org/10.17509/invotec.v11i1.4835

Aronson, E. (1978). The jigsaw classroom. Oxford, England: Sage.

Aronson, E., \& Bridgeman, D. (1979). Jigsaw groups and the desegregated classroom: In pursuit of common goals. Personality and Social Psychology Bulletin, 5(4), 438-336.

Barrie, S. C. (2006). Understanding what we mean by the generic attributes of graduates. Higher Education, 51(2), 215-241. https://doi.org/10.1007/s10734-004-6384-7

Berkhof, M., Van Rijssen, H. J., Schellart, A. J. M., Anema, J. R., \& Van der Beek, A. J. (2011). Effective training strategies for teaching communication skills to physicians: An overview of systematic reviews. Patient Education and Counseling, 84(2), 152-162. https://doi.org/10.1016/j.pec.2010.06.010

Bernstrøm, V. H., Drange, I., \& Mamelund, S. E. (2019). Employability as an alternative to job security. Personnel Review, 48(1), 234-248. https://doi.org/10.1108/PR-09-2017-0279

Bolhuis, S. (2003). Towards process-oriented teaching for self-directed lifelong learning: A multidimensional perspective. Learning and Instruction, 13(3), 327-347. https://doi.org/10.1016/S0959-4752(02)00008-7

Bonwell, C. C., \& Eison, James, A. (1991). Active learning: Creating excitement in the classroom. 1991 ASHE-ERIC Higher Education Reports. In ASHE-ERIC Higher Education Report. https://doi.org/ED340272

Booth, A. (2006). Clear and present questions: Formulating questions for evidence based practice. Library Hi Tech, 24(3), 355-368. https://doi.org/10.1108/LHTN-02-2017-0008

Brickman, P., Gormally, C., Armstrong, N., \& Hallar, B. (2009). Effects of inquiry-based learning on students' science literacy skills and confidence. International Journal for the Scholarship of Teaching and Learning, 3(2), 1-22.

Bridgstock, R. (2009). The graduate attributes we've overlooked: Enhancing graduate employability through career management skills. Higher Education Research and Development, 28(1), 31-44. https://doi.org/10.1080/07294360802444347

Bridgstock, R. (2016a). Educating for digital futures: what the learning strategies of digital media professionals can teach higher education. Innovations in Education and Teaching International, 53(3), 306-315. https://doi.org/10.1080/14703297.2014.956779

Bridgstock, R. (2016b). The university and the knowledge Network: A new educational model for twenty-first century learning and employability. In M. Tomlinson \& L. Holmes (Eds.), Graduate Employability in Context (pp. 339-358). https://doi.org/10.1057/978-1-137-57168-7

Burns, M. E., Houser, M. L., \& Farris, K. L. B. (2017). Theory of planned behavior in the classroom: An examination of the instructor confirmation-interaction model. Higher Education, 75(6), 1091-1108. https://doi.org/10.1007/s10734-017-0187-0 


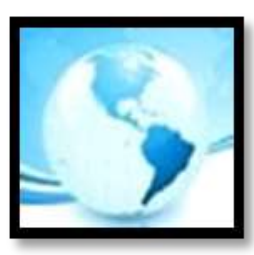

\section{MALAYSIAN ONLINE JOURNAL OF EDUCATIONAL MANAGEMENT (MOJEM)}

Child, J. (2001). Trust-The fundamental bond in global collaboration. Organizational Dynamics, 29(4), 274-288. https://doi.org/10.1016/S0090-2616(01)00033-X

Clanchy, J., \& Ballard, B. (1995). Generic skills in the context of higher education. Higher Education Research \& Development, 14(2), 155-166. https://doi.org/10.1080/0729436950140202

Conti, B., \& Kleiner, B. H. (1997). How to increase teamwork in organizations. Training for Quality, 5(1), 26-29. https://doi.org/10.1108/09684879710156496

Cooper, L., Orrell, J., \& Bowden, M. (2010). Work integrated learning: A guide to effective practice. Oxon: Routledge.

Creswell, J.W. (2013). Research design: Qualitative, quantitative, and mixed methods appoaches (4th ed.). California: Sage Publication, Inc.

Dodgson, M. (1993). Learning, trust and technological collaboration. Human Relations, 46(1), 77-95. https://doi.org/https://doi.org/10.1177/001872679304600106

Durazzi, N. (2018). The political economy of high skills: higher education in knowledge-based labour markets. Journal of European Public Policy, 26(12), 1799-1817. https://doi.org/10.1080/13501763.2018.1551415

Falk, J. H. (1983). Field trips: A look at environmental effects on learning. Journal of Biological Education, 17(2), 137-142. https://doi.org/10.1080/00219266.1983.9654522

Fryman, C., Fei, A., Mehta, R., \& Ahmad, S. (2018). Jigsaw method for non-technical skills in cardiac arrest: A novel application of this active learning pedagogy. Medical Science Educator, 28(2), 401-405. https://doi.org/10.1007/s40670-018-0566-x

Frymier, A. B., \& Houser, M. L. (2000). The teacher-student relationship as an interpersonal relationship. Communication Education, 49(3), 207-219. https://doi.org/10.1080/03634520009379209

Goldman, Z. W., Claus, C. J., \& Goodboy, A. K. (2018). A conditional process analysis of the teacher confirmationstudent learning relationship. Communication Quarterly, 66(3), 245-264. https://doi.org/10.1080/01463373.2017.1356339

Goldman, Z. W., \& Goodboy, A. K. (2014). Making students feel better: Examining the relationships between teacher confirmation and college students' emotional outcomes. Communication Education, 63(3), 259-277. https://doi.org/10.1080/03634523.2014.920091

Hager, P., Holland, S., \& Beckett, D. (2002). Enhancing the learning and employability of graduates: the role of generic skills. Melbourne: Business Higher Education Roundtable, (9), 16. Retrieved from http://hdl.voced.edu.au/10707/108724

Hillage, J., \& Pollard, E. (1998). Employability: Developing a framework for policy analysis. Suffolk, England: Department for Education and Employment. Retrieved from http://hdl.voced.edu.au/10707/10058

Hmelo-Silver, C. E., Duncan, R. G., \& Chinn, C. a. (2007). Scaffolding and achievement in problem-based and inquiry learning: A response to Kirschner, Sweller, and Clark (2006). Educational Psychologist, 42(2), 99-107. https://doi.org/10.1080/00461520701263368 


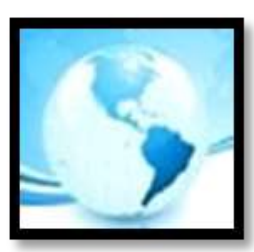

\section{MALAYSIAN ONLINE JOURNAL OF EDUCATIONAL MANAGEMENT (MOJEM)}

Hofstein, A., \& Lunetta, V. N. (2004). The laboratory in science education: Foundations for the twenty-first century. Science Education, 88(1), 28-54. https://doi.org/10.1002/sce.10106

Howell, W. L., \& Schwab, K. (2018). Future - World Economic Forum. Retrieved from www.weforum.org

Husamah, Y. P. (2015). Thinking skills for environmental sustainability perspective of new students of biology education department through blended project based learning model. Jurnal Pendidikan IPA Indonesia, 4(2), 110-119. https://doi.org/10.15294/jpii.v4i2.3878

Johnson, D. W., Johnson, R. T., \& Stanne, M. B. (2000). Cooperative learning methods : A meta-analysis. Retrieved from http://www.academia.edu/download/33787421/Cooperative_Learning_Methods_A_Meta-Analysis.pdf

Kaeser, J. (2018). The world is changing. Here's how companies must adapt. World Economic Forum. Retrieved from https://www.weforum.org/agenda/2018/01/the-world-is-changing-here-s-how-companies-must-adapt

Karpouza, E., \& Emvalotis, A. (2019). Exploring the teacher-student relationship in graduate education: A constructivist grounded theory. Teaching in Higher Education, 24(2), 121-140. https://doi.org/10.1080/13562517.2018.1468319

LaBelle, S., \& Johnson, Z. D. (2018). Student-to-student confirmation in the college classroom: The development and validation of the student-to-student confirmation Scale. Communication Education, 67(2), 185-205. https://doi.org/10.1080/03634523.2018.1427879

Lee, C. K., \& Al-Hawamdeh, S. (2002). Factors Impacting Knowledge Sharing. Journal of Information \& Knowledge Management, 1(1), 49-56. https://doi.org/10.1142/s0219649202000169

Liao, S. N., Griswold, W. G., \& Porter, L. (2018). Classroom experience report on jigsaw learning. ITiCSE, 302-307. https://doi.org/10.1145/3197091.3197118

Martens, B., \& Tolan, S. (2018). Will this time be different? A review of the literature on the impact of artificial intelligence on employment, incomes and growth. JRC Digital Economy Working Paper, 2018-08. https://doi.org/10.2139/ssrn.3290708

Maynard, T., \& Waters, J. (2007). Learning in the outdoor environment: A missed opportunity? Early Years, 27(3), 255-265. https://doi.org/10.1080/09575140701594400

Moreau, M. P., \& Leathwood, C. (2006). Graduates' employment and the discourse of employability: A critical analysis. Journal of Education and Work, 19(4), 305-324. https://doi.org/10.1080/13639080600867083

Morley, L. (2002). Producing new workers: Quality, equality and employability in higher education. Quality in Higher Education, 7(2), 131-138. https://doi.org/10.1080/13538320120060024

Nugraha, A., Hasan, S. U. N., \& Annisa, F. N. (2016). Kegiatan kemahasiswaan: strategi untuk meningkatkan kompetensi lulusan di perguruan tinggi [Student activities: strategies to improve the competence of graduates in tertiary institutions]. Prosiding Seminar Nasional Optimalisasi Active Learning Dan Character Building Dalam Meningkatkan Daya Saing Bangsa Di Era Masyarakat Ekonomi Asean (MEA) [Proceedings of the National Seminar on Optimizing Active Learning and Character Building in Improving the Nation's Competitiveness in the Era of the Asean Economic Community], 170-173. 


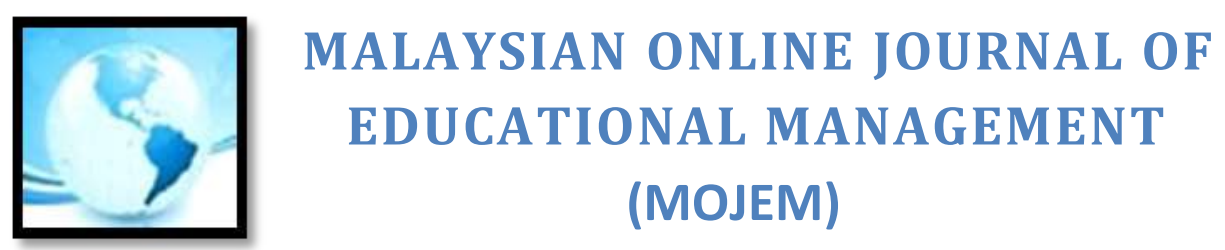

Orion, N. (1993). A model for the development and implementation of field trips as an integral part of the science curriculum. School Science and Mathematics, 93(6), 325-331. https://doi.org/10.1111/j.19498594.1993.tb12254.x

Pedaste, M., Mäeots, M., Siiman, L. A., de Jong, T., van Riesen, S. A. N., Kamp, E. T., ... Tsourlidaki, E. (2015). Phases of inquiry-based learning: Definitions and the inquiry cycle. Educational Research Review, 14, 47-61. https://doi.org/10.1016/j.edurev.2015.02.003

Ristanto, R. H., Zubaidah, S., Amin, M., \& Rohman, F. (2018). The potential of cooperative integrated reading and composition in biology learning at higher education. International Journal of Educational Research Review, 3(2), 50-56. https://doi.org/10.24331/ijere.376727

Salas, E., Shuffler, M. L., Thayer, A. L., Bedwell, W. L., \& Lazzara, E. H. (2015). Understanding and improving teamwork in organizations: A scientifically based practical guide. Human Resource Management, 54(4), 599622. https://doi.org/10.1002/hrm.21628

Slavin, R. E. (1986). Using student team learning: The Johns Hopkins Team Learning Project. Baltimore: The Johns Hopkins University.

Sternberg, R. J., Grigorenko, E. L., \& Zhang, L. (2008). Styles of learning and thinking matter in instruction and assessment. Perspectives on Psychological Science, 3(6), 486-506. https://doi.org/10.1111/j.17456924.2008.00095.x

Støren, L. A., \& Aamodt, P. O. (2010). The quality of higher education and employability of graduates. Quality in Higher Education, 16(3), 297-313. https://doi.org/10.1080/13538322.2010.506726

Suleman, F. (2018). The employability skills of higher education graduates: Insights into conceptual frameworks and methodological options. Higher Education, 76(2), 263-278. https://doi.org/10.1007/s10734-017-0207-0

Tarricone, P., \& Luca, J. (2002). Employees, teamwork and social interdependence - a formula for successful business? Team Performance Management: An International Journal, 8, 54-59. https://doi.org/10.1108/13527590210433348

Tobias, S. (1994). Interest, prior knowledge, and learning. Review of Educational Research, 64(1), 37-54.

Tobin, K. (1990). Research on science laboratory activities: In pursuit of better questions and answers to improve learning. School Science and Mathematics, 90(5), 403-418. https://doi.org/10.1111/j.19498594.1990.tb17229.x

Voogt, J., \& Roblin, N. P. (2012). A comparative analysis of international frameworks for $21^{\text {st }}$ century competences: Implications for national curriculum policies. Journal of Curriculum Studies, 44(3), $299-321$. https://doi.org/10.1080/00220272.2012.668938

Wang, S., \& Noe, R. A. (2010). Knowledge sharing: A review and directions for future research. Human Resource Management Review, 20(2), 115-131. https://doi.org/10.1016/j.hrmr.2009.10.001

Weidman, R., \& Bishop, M. J. (2009). Using the jigsaw model to facilitate cooperative learning in an online course. The Quarterly Review of Distance Education, 10(1), 51-64. 


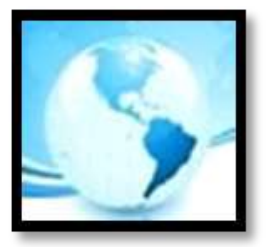

\section{MALAYSIAN ONLINE JOURNAL OF EDUCATIONAL MANAGEMENT \\ (MOJEM)}

Wolff, R., \& Booth, M. (2018). Bridging the gap: Creating a new approach for assuring 21st century employability skills. Change: The Magazine of Higher Learning, 49(6), 51-54. https://doi.org/10.1080/00091383.2017.1399040 